\title{
Assessing English Language Teaching Student Teachers on Teaching Practice
}

Dhanapati Subedi

\begin{abstract}
The implementation of teaching practice in ELT is an effective way in improving practices of our student teachers. This study therefore focuses on assessment of teaching practice conducted by the School of Education, Kathmandu University for M.Ed ELT student teachers. A total of 16 student teachers, 100 students, 16 co-teachers and 16 principals of higher educational institutions involved in the study. The study reveals that there has been an improvement in teaching practice particularly on classroom dynamics. However enough training on lesson plan preparation, presentation, class management, communication skills, evaluation and project work is necessary to our student teachers in order to improve English language teaching. The study is expected to be useful to academic planners, ELT planners, curriculum designers, textbook writers, teachers and practitioners.
\end{abstract}

Key words: Teaching practice, reflection, student-teachers, lesson plan

\section{Introduction}

Kathmandu University, School of Education (KUSOED) started its Master of Education (M. Ed.) in English Language Teaching (ELT) program in 2003 with the aim of preparing competent and transformative teachers, teacher trainers, material developers and researchers who could contribute for the development of education in the country. Brian (2005) says that professionals and students in the helping professions consider internships, practicums and field placements among the most influential experiences of their careers. Similarly Sharma points out that "teaching practice is an essential aspect of ELT program. It integrates classroom theory with practical work experience in the public sector or in a private setting. It is based on the premise that learning in the work world can enhance the learning in the classroom. It is geared towards preparation of new teacher into the teaching profession' (2009:1). Highlighting the importance of practice teaching, Afolabi (1999) advocates:
Opportunities to practice teaching behaviors are probably amongst the most valuable training experiences afforded to prospective teachers However, many teacher education programs fail to fully exploit and utilize the full potential of practical teaching experiences for their student teachers and many programs also fail to maximize opportunities to forge stronger connections between theory and practice.

Cohen, Manion, \& Morrison (2008) say, 'the current situation in schools is one of the permanent flux, with many innovations and developments designed to boost learning, raise standards and achievement, energize learning and meet the diverse needs and conditions of learners'(p.4). Many school authorities in Nepal do not accept student teachers to practice at their schools. There are several reasons like less qualified, short time teaching, students take their lessons lightly, irregularity and so on. However, there are certain innovations that the student teachers can bring. In this situation, just observing 
student teachers and giving marks does not change the way the school authorities think. There has to be an in-depth study of the effectiveness of the teaching practice in English language teaching.

Therefore, this study is an attempt to investigate the effectiveness of teaching practice program in English language teaching. The study would provide useful information as regards the assessment of the student teachers' practice and assist in improving teaching practice program in the School of Education. It would also put the school authority in a better position to explore ways of improving the supervisory skills of supervisors and consequently the efficiency of teaching practice program.

\section{Objectives of the study}

The main objective of this study was to find out the effectiveness of teaching practice program conducted by the School of Education, Kathmandu University. However the study had the following specific objectives:

- To assess the lesson delivery of the student teachers in their practical settings

- To obtain students' feedback on student teachers' performance

- To obtain co- teachers' and principals' feedback on student teachers' performance

- To document reflections of teaching practice by student teachers

\section{Methodology}

The study is geared up with phenomenological stand point as it is depicting the reality. The participants in this study were M. Ed in English language teaching student teachers who were in the third semester of their degree. Sixteen student teachers of the School of Education Kathmandu University were sent to sixteen higher secondary schools (eight public and eight private) of Kathmandu Valley for the teaching practice. The schools were selected based on the access and student- teachers' convenience. In the first stage of practice teaching, the students observed the lessons by the co-operating teacher. The two discussed the lesson before and after the class. In the second stage of practice teaching, the student and the cooperating teacher planned and delivered lesson together. They also discussed the lesson after the class. In the third stage of practice teaching, the student planned the lesson and the co-operating teacher went through it and suggested any necessary modification. The co-operating teacher observed the student's class and gave feedback after the class. Internal supervisor from the school of education observed student teachers' classes and video recorded their classroom teaching throughout the session. After two months of their practice teaching, they were evaluated using the evaluative guidelines developed by the school of education. I conducted open ended interview to 100 students of the sixteen schools, sixteen co- teachers and sixteen principals to obtain feedback of the student teachers' performance. Video recording, lesson plans, peer observation forms, logbooks and reflective diaries of each of the student teachers were observed. Field data were recorded and tabulated on the basis of themes. Data were reality based because they were collected from the real field where the student teachers involved in the teaching practice. They were legitimated because student teachers, principals, co-teachers and students involved in the process and reflected their ideas. The data were representative because 100 students were selected using systematic random sampling procedure. The researcher transcribed the information generated from the field. A separate school report was prepared. Field level data were checked and verified again and again to ensure reliability. Common findings, observations and information were combined together. Similarly, Specific and contrast findings were recorded separately. Likewise, reflective diaries of the student teachers' were collected, processed and documented. Following this, the researcher prepared the consolidated report.

\section{Findings and Discussions}

Based on the information generated from the field and interview with key stakeholders of the teaching practice program of the School of Education, the summary findings are organized under major themes. The major themes the findings were 
organized and presented are: preparation, transition of the lesson, instruction, evaluation, management feedback and reflection.

\section{Preparation}

There was not uniformity in writing / preparing lesson plans: some were in detail, some were in a short form, and some were found exact downloaded lesson plans from the internet. The commonality found in their lesson planning was that they wrote up terminal performance objectives (TPO), activities to be performed by the student teachers and instructional materials clearly. The approaches of English language teaching were overlooked in the preparation of their lesson plans. This gives a direction to the English language teacher to focus on approaches while teaching to their students.

\section{Transition of the Lesson}

Student teachers were found tactful to bridge the gap between previous lesson and the subsequent lesson. This shows that they have developed a required knowledge and skills to co-ordinate the transition of lessons. The common aspect observed in their class initiation was that they initiated either with warming up activities or with brain storming activities. English language teaching in the public schools found quite difficult because of the large number of students, lack of teaching materials and poor English language proficiency of the students. One of our student teachers tried to warm the students up using a joke from the foreign context for grade eleven students. As she finished her joke, I observed nobody laughed at all except her. This proves that the instructional pedagogy has to be contextualized. They could have laughed if she had said a joke Dolma and Jamuna from the Nepali context. This gives a direction to the textbook writers and ELT teachers to write content of the local context rather than copying and collecting the texts from the foreign context.

\section{Instruction}

Student teachers tried to motivate their students saying 'This lesson is very important for the examination.' This shows that in our practice the education system has been cultivating exam oriented teaching culture rather than knowledge oriented teaching. The student teachers used different materials like whiteboard, cardboard, flashcards etc. but the letters on cardboard and pictures they prepared were not readable. During the internal and external evaluation periods, many students hired multimedia to deliver their sessions effectively. This shows that they have been failure to promote locally available materials and their usage while teaching English language and the rigorous mentoring is necessary to prepare the teaching materials. They encouraged questions and students' participation using appropriate methods and techniques. They were found competent over English language and they focused more on activities rather than lecturing. Many student teachers forgot to summarize and evaluate the students to find out whether the objectives have been achieved or not.

\section{Evaluation}

They used variety of evaluation tools-- written, oral, observation and group activities but one innovation in their evaluation found was that they did not provide immediate feedback. They tried to correct the mistakes committed by the students. They were found to correct the assignments submitted by the students and provided home assignments. This proves the fact that they applied theories of testing and evaluation to their classroom teaching.

\section{Management}

They were successful to manage classroom activities. They maximized students' time on task ensuring their level of understanding and assisting to develop productive work habits. Sitting arrangements were poor in the public schools as compared to private schools. However, student teachers were able to maintain discipline among students.

\section{Feedback}

Students were found very interested in the student teachers' performance. They emphasized the practicality of the student teachers' teaching. They specified saying student teachers' style of teaching is quite interesting. They prepare lesson plan, bring a lot of materials and display. They sometimes tell a joke. They often ask the questions which encourage me to read the lesson. They always end their lesson 
with a summary and innovative project works. One student said:

I am very interested to learn at her class. In other classes, 45 minutes is a kind of punishment like but in her class, how the time passes on I don't know. As she says, this is all about today's session I wish she had more time allocated for leaching us.

Principals were positive towards the efforts of student teachers and practice teaching program as a whole. For them, teaching practice is crucial because it promotes quality of teaching. They welcomed the student teachers' placement at their schools. They thought that student teachers with this kind of practice can develop professionalism and will be successful to make a kind of linkage with educational organizations. One principal said:

We are very happy that KUSOED posted such an energetic, innovative and qualified student teacher to teach at our school. She has been teaching very effectively. I often walk around and observe her way of teaching which is admirable. I wish if we had such innovative and practical ideas to teach.

The above text suggests that principals have a positive attitude towards KUSOED. They have confidence over KUSOED's product. The school had a system of supervising class room teaching and KUSOED has a big reputation in the educational settings in Nepal.

Co- teachers found to have a very positive feedback towards KUSOED's student teachers' teaching. They said that practice teaching is an integral part of education which has heightened the value of the trained teachers in the market. For them, just lecturing for an hour does not give a worth effective results in teaching. Teaching students with getting them involved into different interesting and innovative activities produces worth effective results. They focused on how aspect of teaching rather than what aspect. For them, students were very intelligent and skill- oriented to deliver and manage the class. They also expressed a negative view on teaching practice stating that the student teachers teach nicely during the practice teaching but the same way of teaching does not remain when they are employees of a school which was a reality for them. They said teaching practice is the exciting but challenging task of assimilating a variety of contexts. As one of the co- workers said:

I am M.A English. I don't know methodologies but have been teaching for 15 years. Now I have realized that there is a generation gap between us (elder teachers and younger teachers). They can deliver what they really want in English. But we take a help of Nepali language. We speak more in Nepali language than English.

The above text reveals that the importance of methodology has been realized by a teacher after 15 years of his teaching which is equally important for those who are having their degree in M.A. The text also reflects that there is a realization of the generation gap. Younger teachers as reported by a co teacher found comfortable to deliver the session in the classroom which is a sign of improvement in English language teaching in Nepal.

\section{Reflection from the Student Teachers}

The concluding sentences of reflections on teaching practice by some student teachers form their journals below prove that teaching practice is an indispensible component which provides opportunity to prospective teachers to implement the theories, instructional techniques and share the experiences for developing confidence, teaching attitudes and skills under the supervision and guidance of the expert educators.

Rishav Dev Khanal: Every day there was something new that I realized I did not know before. If for no other reason than that, I'm glad I did an internship.

Ranjit Rai : I've learned more in this experience than I have in any of my classes.

Vimlal Shrestha : I am very happy to be one of the interns in the practice teaching program. Now, I can teach the students using different methods and techniques.

Deepak Dulal : I have developed a confident over teaching which I had not before. Practice teaching purifies our ways of teaching. 
Anil Bhusal : Practice makes a man skillful and erudite. Now I have realized the importance of teaching practice. In the very first day, I was nervous but now I think I can teach to the students confidently.

Usha Bhusal: In the initial phase of the posting at this school, I was scared with a large class having 60 students. They asked irrelevant questions: Miss you look like a student of this class. Can you really teach us? As the time went on, they started to give a complement on my teaching saying: Miss your class is very interesting so we never miss your class.

Udhab Bhattarai: Teaching in the actual classroom setting is something different than what we learn in our classroom theoretically.

\section{Conclusion and Recommendation}

The practice teaching program conducted at sixteen higher secondary schools of Kathmandu valley from the School of Education, Kathmandu University completed successfully. It became effective for all the stakeholders. Principals, co-teachers and students of the schools co-operated the student teachers throughout their posting period. The program exposed the student teachers to different processes of learning through preparing work plan, linkage with the institutions, work performance, professional relationships and personal role. The program offered the student teachers ample opportunities to contribute and reflect their own experiences, perceptions and opinions. The student teachers developed self-confidence as well. Teaching practice is an essential part of educational program at the School of Education. It prepares student teachers for future challenges through acquisition of relevant skills. It is therefore important to focus on approaches of English language teaching, by English language teachers of the KUSOED. They should impart knowledge rather than skill enhancing strategies, discourage exam oriented culture of teaching and mentor student teachers to prepare locally available materials for English language teaching. The trend in English language teaching in Nepal from Kathmandu University is confined to classroom activities focusing on greeting, motivation/warm up, revision of the previous lesson, introduction, initiation of the lesson, presentation, evaluation, rounding up and homework. However there has to a focus on pre-classroom activities like fluency, command over subject matter, appropriate approaches, methods and techniques and suitable teaching aids.

\section{Pedagogical Implications}

From the whole study, the following pedagogical implications can be drawn to improve our practices of English language teaching.

Teaching practice gives high priority to school placements which is an integral part of teacher education. An introduction to the realities of the situation is an essential part of effective professional training. This process also allows the student teacher an opportunity to determine whether the appropriate choice has been made.

The aims of the teaching practice experience are to provide opportunities for student teachers to integrate theory and practice and work collaboratively with and learn from the teachers.

Student teachers observe subject teachers at work so as to learn about teachers' skills, strategies and classroom achievements. They also evaluate their own teaching experiences through conferencing with teachers and lecturers and, through self-reflection, implement a variety of approaches, strategies and skills with a view to bring about meaningful learning.

In this way student teachers gain experience in managing and evaluating class work; in maintaining discipline and good order in the classroom; find their own teaching style and personality and become acquainted with school organization and administration.

Dhanpati Subedi is an Assistant Professor at the School of Education, Kathmandu University. He has a background in teaching pragmatics and discourse analysis, computer assisted language learning (CALL), action research, study skills and academic writing. He has an M.Phil Degree in Educational Leadership and a Master's degree in English Education. He is a life member of NELTA and has published an article entitled 'Rosetta Stone Software for Language Skills Improvement in the EFL Classroom: An Action Research Report' in the Journal of the IATEFL SIG. 


\section{References}

Afolabi, S.O. (1999). The philosophy of supervision in education. Journal of Kwara State College of Education, 1, 39-48.

Baird, N.B. (2005). The internship practicum and field placement handbook. USA: Pearson Prentice Hall.
Cohen, L., Manion, L. \& Morrison, K. (2008). A guide to teaching practice. London: Falmer Press.

Cohen, L., Manion, L. \& Morrison, K. (1994). Research methods in education. New York: Routledge.

Sharma, T.N. (2009). Internship handbook. Balkumari: Kathmandu University, School of Education.

\section{APPENDIXA:}

\section{Evaluative Guideline}

\begin{tabular}{|c|c|c|}
\hline $\begin{array}{l}\text { School: } \\
\text { Teacher' }\end{array}$ & me: & \\
\hline Time: & & Class: \\
\hline Topic : & & $\begin{array}{l}\text { Period: } \\
\text { Date: }\end{array}$ \\
\hline Minute: & Activities(Please write the major activities) & \\
\hline $1-5$ & & \\
\hline $6-15$ & & \\
\hline $16-25$ & & \\
\hline 26-45 & & \\
\hline
\end{tabular}

\section{APPENDIX B:}

\section{Video Recorded Files}

\begin{tabular}{|c|c|c|}
\hline S.N & Student & Files \\
\hline 1 & S1 & 1 \\
\hline 2 & S2 & 2 \\
\hline 3 & & 3 \\
\hline 4 & S3 & 4 \\
\hline 5 & S4 & 5 \\
\hline 6 & S5 & 6 \\
\hline 7 & S6 & 7 \\
\hline$\ldots$ & S7 & \\
\hline
\end{tabular}

$\mathrm{S}=$ Student 


\section{APPENDIX C}

\section{Reflective Diary}

Date: $16^{\text {th }}$ Sep, 2009

We, the M. Ed. in ELT students of Kathmandu University were assigned to find a college and teach the college students preparing a lesson plan for each lesson. We, Uddab Bhattarai and Rishav Dev Khanal were also given a letter for the concerned principal requesting to provide teaching ground to us. As a student teacher, we visited many colleges in Kathmandu. After a long walk, we found a school; Ratna Rajya Higher Secondary school at Baneshwor. Uddhab and I talked together and decided to work there if we were provided the chance. At the beginning, we met the subject teacher Mr. K.B. Gurung who was an experienced and was very helpful. He was suggested us to meet the principal. We met the Principal, Mrs. Geeta Kharel. She was also very helpful. She welcomed us and allowed us to b a part of her teaching team. She immediately called the subject teacher and asked him to manage a class for us.

\section{The First Day Experience}

As we had confidence in us that we would face any type of challenge that could come in front of us, we decided to lead the lesson turn wise. On he very first day, the subject teacher, K.B. sir introduced us to the class and allowed us to teach

We were prepared with a lesson 'Introduction'. Uddab and I presented the lesson cooperating each other.

It was quite different experience to have collaborative teaching, but we enjoyed a lot. . At the end of the class, the teacher provided us some positive feedback. He praised our teaching style and the language we used. He also requested us to use Nepali language some times to make the students understand he subject matter, we denied it and convinced him telling that we would use examples, gestures and use only English language in the class. He relied on us and accepted our proposal.

\section{How we led the lesson}

We continued our lesson, the more familiar the students became the easier we felt to teach them. We focused on the communicative approach as the students were mostly from the government schools and had weak base in English. But very interesting thing we found was that, all the students were eager to speak although they had problem with vocabulary and structure. We encouraged them to take part in discussion and they did as much they could. After a week, we started to teach link English and the magic of words.

\section{What the reflection of the students was}

As we had found the needs of the students and led the lesson practically, involving them in speaking and writing, they were happy to learn with us. Every day they were found to be more interested in taking part in discussion. They used to perform the work in the class properly, and were ready to revise as given by the teachers. At the end of the month we had asked for the feed back in the written form, and they have provided it with their own hand writings. However, it was a short term teaching, and we couldn't continue we are confident that the students are most benefited and we got ample opportunity to gain experience to teach in the college. Now, we are confident that we can teach the college students of Intermediate and even bachelor level. 


\section{APPENDIX D}

Interview Guideline (students', co-teachers' and principals' statements are video recorded)

How do you evaluate student teacher and his/her way of teaching?

Are you satisfied with his/ her teaching? 